\title{
Dysglycemia and Arthroplasty Outcomes: A Review
}

\author{
Talal Alkindy ${ }^{1}$ \\ 1. Orthopaedics, University of Tabuk, College of Medicine, Tabuk, SAU
}

Corresponding author: Talal Alkindy, kindy99@hotmail.com

\begin{abstract}
Arthroplasty (ART) is a common surgery and it is on the rise worldwide due to increasing longevity and osteoarthritis. The effects of perioperative hyperglycemia on the outcomes are largely unknown and the current review aimed to assess the impact of perioperative hyperglycemia on ART outcomes.

The literature in PubMed and Google Scholar was searched for relevant articles published in the last ten years up to February 2020. The keywords knee ART, hip ART, diabetes mellitus (DM) impaired fasting glucose (IFG), impaired glucose tolerance (IGT), and impaired glycated hemoglobin (HbA1c) were used. Among the 113 articles retrieved, 34 full-texts were eligible, and only 21 studies (17 from the USA, three from Europe, and two from Asia) met the inclusion criteria for the systematic review. The authors' names, year of publication, country, type of study, number of patients, and duration of the study were reported.
\end{abstract}

The studies reviewed showed high ART complication rates including infections, loosening, increasing severity and depth of infection, more pain, and higher costs with high perioperative hyperglycemia. The cutoff glycated hemoglobin values associated with complications ranged from 6.7 to $>8$.

Received 08/18/2020

Review began 08/28/2020

Review ended 08/28/2020

Published 09/04/2020

() Copyright 2020

Alkindy. This is an open access article distributed under the terms of the Creative Commons Attribution License CC-BY 4.0., which permits unrestricted use, distribution, and reproduction in any medium, provided the original author and source are credited.
Categories: Endocrinology/Diabetes/Metabolism, Orthopedics

Keywords: the impact of diabetes mellitus and prediabetes on arthroplasty outcomes, a review

\section{Introduction And Background}

Arthroplasty (ART) is not uncommon. Seven million people were living with knee and hip ART in the US in the year 2010 with a prevalence of $0.83 \%$ to $10.38 \%$ depending on age and sex, and the procedure is on the rise worldwide due to the burden of osteoarthritis and increasing longevity [1,2]. ART, like other surgery, is not without local and general complications including loosening, hemorrhage, and deep vein thrombosis [3]. Currently, 374 million people 20-79 years old have impaired glucose tolerance (IGT; prediabetes) and 463 are suffering from diabetes mellitus (DM) [4], most of whom are undiagnosed. The impact of DM and prediabetes on ART is a matter of controversy as is which test (impaired fasting glucose (IFG), IGT, or glycated hemoglobin) is preferred. Thus, we conducted this review to assess the impact of DM and prediabetes on ART.

\section{Review \\ Methods}

Eligibility Criteria According to PICOS

Type of study: All articles in English language (observational studies) assessing the effects of diabetes and prediabetes on ART (both upper and lower limb ART) outcomes published during the last ten years up to February 2020 were eligible. Studies were eligible if they were longitudinal (prospective or retrospective studies, prospective cohort, case-control, nested case-control that reported the association of ART (knee or shoulder) outcomes in term of superficial or deep infections, loosening, cost, hospital stay, and pain with dysglycemia (impaired fasting plasma glucose, IGT, or high HbA1c). Studies examining any type of infection were approached (periprosthetic joint infection, deep infection, deep surgical site infection, or deep prosthetic infection). We complemented the search by manual scanning of reference lists of identified articles. The search was limited to studies conducted in humans.

Exclusion criteria: Case series studied, case reports, and animal studies and studies published in languages other than English were excluded. Operations during childhood were excluded from the study.

Type of participants: Adult patients who underwent ART (in the upper and lower limbs) and were diagnosed with diabetes or prediabetes during the last ten years up to February 2020.

Type of outcome measures: We included studies if they measured at least one of the following outcome measures: infections (deep or superficial), wound complications, postoperative pain, aseptic loosening, 


\section{Cureus}

length of stay, hospital costs, and mortality.

Information sources and search methods: A systematic manual search was conducted in PubMed (including ahead of print and Epub) and the first hundred articles of Google Scholar databases published in the last ten years up to February 2020. The keywords used were those related to exposure including knee ART, hip ART, DM-impaired fasting glucose, impaired glucose tolerance, dysglycemia, undiagnosed diabetes, and impaired HbA1c with those related to outcomes (e.g., wound infection, loosening, pain, cost, and hospital stay with protean AND or OR. Among the 113 articles retrieved, 34 full-texts were eligible, and only 22 studies (17 retrospective studies, two prospective cohorts, two case-control studies, and one cross-sectional study) met the inclusion criteria for the systematic review. The author's name, year of publication, country, type of study, number of patients, and the duration of the study were reported.

Titles and abstracts were screened by the author and full texts retrieved for the manuscripts found relevant for the topic and excluded clearly irrelevant articles. Additional articles were searched and identified through hand searching of the bibliography. The retrieved full-text articles were assessed for eligibility for inclusion and data were extracted by the authors using proforma. Any disagreement in the selection of articles and data was solved by consensus. Figure 1 illustrated the different phases of the literature search. 


\section{Cureus}

113 records identified through the

database search

Limiting the search

criteria \& avoidance

of duplication

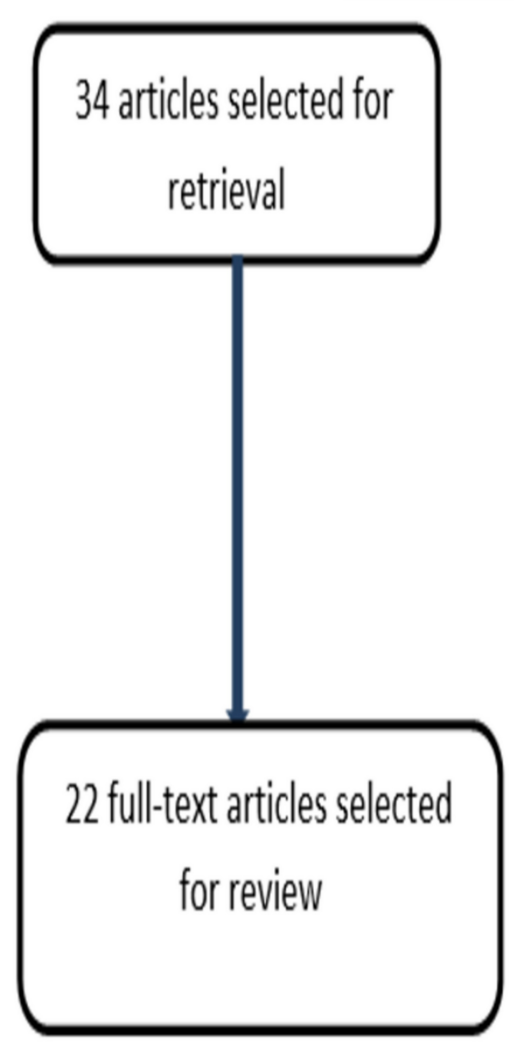

FIGURE 1: The different phases of the literature search

Assessment of Risk of Bias in Included Studies

For the assessment of study quality, the risk of bias assessment according to Newcastle-Ottawa was applied in Table 1 . 


\section{Cureus}

\begin{tabular}{|c|c|c|c|}
\hline Author & Selection & Compatibility and outcome & Total score \\
\hline Mravoic et al. [5] & 4 & 3 & 7 \\
\hline Jamsen et al. [6] & 4 & 5 & 9 \\
\hline Strykler et al. [7] & 4 & 5 & 9 \\
\hline Adams et al. [8] & 4 & 5 & 9 \\
\hline Chastil et al. [9] & 4 & 3 & 7 \\
\hline Maradit Kremers et al. [10] & 4 & 3 & 7 \\
\hline Rajamäki et al. [11] & 4 & 4 & 8 \\
\hline Hwang et al. [12] & 4 & 4 & 8 \\
\hline Brock et al. [13] & 4 & 4 & 8 \\
\hline Maradit Kremers et al. [14] & 4 & 5 & 9 \\
\hline Cancienne et al. [15] & 4 & 3 & 7 \\
\hline Tarabichi et al. [16] & 4 & 4 & 8 \\
\hline Capozzi et al. [17] & 4 & 3 & 7 \\
\hline Lavernia et al. [18] & 4 & 3 & 7 \\
\hline Cancienne et al. [19] & 4 & 3 & 7 \\
\hline Godshaw et al. [20] & 4 & 3 & 7 \\
\hline Kurowicki et al. [21] & 4 & 4 & 8 \\
\hline Kheir et al. [22] & 4 & 4 & 8 \\
\hline Shohat et al. [23] & 4 & 3 & 7 \\
\hline Lenguerrand et al. [24] & 4 & 4 & 8 \\
\hline Ryan et al. [25] & 4 & 3 & 7 \\
\hline Shohat et al. [26] & 4 & 4 & 8 \\
\hline
\end{tabular}

\section{TABLE 1: Quality of the selected studies by using the Newcastle-Ottawa scale}

\section{Results}

A total of 113 studies were identified through the database search. Out of the 34 full texts retrieved, only 22 were included in the review (17 retrospective studies, two prospective cohorts, two case-control studies, and one cross-sectional), 17 were published in the USA, three from Europe, and two were from Asia, 104,342 patients included. All the retrospective studies showed the association of perioperative hyperglycemia with ART infection and loosing; however, there are mixing results regarding the HbA1c cut-off at which infections and other complications were observed (the HbA1c ranged from 6.7 to 8), the two prospective cohorts concluded the increased complications among both diagnosed and undiagnosed patients with diabetes and suggested that fructosamine is more accurate than the HbA1c ( $293 \mu \mathrm{mol} / \mathrm{l}$ was identified as the optimal cutoff associated with complications). The case-control studies retrieved showed mixed results with one study stated that preoperative glycemic control on the length of stay, hospital costs, or rate of short-term postoperative complications, while the other concluded less improvement observed among patients with $\mathrm{DM}$ at I year and more at $\mathrm{HbA1c}>8$. The results showed that both postoperative hyperglycemia and the HbA1c were shown to be associated with joint infections; however, this effect was lost after controlling for BMI, type of surgery, and operative time. The studies showed conflicting results regarding the length of stay, hospital costs, or rate of short-term postoperative complications. The association was again attenuated after controlling for obesity and other comorbidities. Table 2 depicted the association between ART outcomes, diabetes, and prediabetes.

\begin{tabular}{|l|l|l|l|l|}
\hline Author & Year & Country & Study type & Patients \\
\hline
\end{tabular}




\section{Cureus}

\begin{tabular}{|c|c|c|c|c|c|}
\hline $\begin{array}{l}\text { Mraovic et } \\
\text { al. [5] }\end{array}$ & 2011 & USA & Retrospective & 1948 & $\begin{array}{l}\text { DM and morning postoperative hyperglycemia were predictors } \\
\text { for postoperative infection, also, high BMI and comorbidities }\end{array}$ \\
\hline $\begin{array}{l}\text { Jämsen et } \\
\text { al. [6] }\end{array}$ & 2012 & Finland & Retrospective & $\begin{array}{l}7181 \text { total knee } \\
\text { and hip ART }\end{array}$ & $\begin{array}{l}\text { DM doubled the rate of infections especially when associated } \\
\text { with morbid obesity, postoperative of } 124 \mathrm{mg} \text { is suggested. }\end{array}$ \\
\hline $\begin{array}{l}\text { Stryker et al. } \\
\text { [7] }\end{array}$ & 2013 & USA & Retrospective & 1702 joint ART & $\begin{array}{l}\text { Postoperative blood glucose of }>200 \mathrm{mg} / \mathrm{dL} \text { or a preoperative } \\
\text { hemoglobin A1C level of }>6.7 \% \text { are predictors for wound } \\
\text { complications }\end{array}$ \\
\hline $\begin{array}{l}\text { Adams et al. } \\
{[8]}\end{array}$ & 2013 & USA & Retrospective & $\begin{array}{l}40,491 \text { total } \\
\text { knee ART }\end{array}$ & $\begin{array}{l}\text { No differences between diabetes } \mathrm{HbA} 1 \mathrm{c}<7 \text { or more and } \\
\text { comparators regarding complications }\end{array}$ \\
\hline $\begin{array}{l}\text { Chrastil et } \\
\text { al. [9] }\end{array}$ & 2015 & USA & Retrospective & 13,272 joint ART & $\begin{array}{l}\text { Increased infections with perioperative hyperglycemia, but not } \\
\text { HbA1c (high mortality) }\end{array}$ \\
\hline $\begin{array}{l}\text { Maradit } \\
\text { Kremers et } \\
\text { al. [10] }\end{array}$ & 2015 & USA & Retrospective & $\begin{array}{l}20,171 \text { total hip } \\
\text { and knee ART }\end{array}$ & $\begin{array}{l}\text { No association of perioperative hyperglycemia and diabetes with } \\
\text { prosthetic joint infections after controlling for BMI, type of } \\
\text { surgery, and operative time. }\end{array}$ \\
\hline $\begin{array}{l}\text { Rajamäki et } \\
\text { al. [11] }\end{array}$ & 2015 & Finland & $\begin{array}{l}\text { Cross- } \\
\text { sectional }\end{array}$ & $\begin{array}{l}193 \text { knee and } \\
\text { hip }\end{array}$ & Increased postoperative pain among patients with diabetes \\
\hline $\begin{array}{l}\text { Hwang et al. } \\
{[12]}\end{array}$ & 2015 & Korea & Retrospective & $\begin{array}{l}462 \text { total knee } \\
\text { ART }\end{array}$ & $\begin{array}{l}\mathrm{FBS} \geq 200 \mathrm{mg} / \mathrm{dl} \text { and } \mathrm{HbA} 1 \mathrm{c} \geq 8 \text { strongly correlate with superficial } \\
\text { infections }\end{array}$ \\
\hline $\begin{array}{l}\text { Brock et al. } \\
{[13]}\end{array}$ & 2017 & UK & Case-control & $\begin{array}{l}200 \text { total knee } \\
\text { ART }\end{array}$ & $\begin{array}{l}\text { Less improvement observed among patients with DM at I year } \\
\text { and more at } \mathrm{HbA} 1 \mathrm{c}>8\end{array}$ \\
\hline $\begin{array}{l}\text { Maradit } \\
\text { Kremers et } \\
\text { al. [14] }\end{array}$ & 2017 & USA & Retrospective & $\begin{array}{l}16,085 \text { knee and } \\
\text { hip ART }\end{array}$ & $\begin{array}{l}\text { High preoperative hyperglycemia is a potential risk factor for } \\
\text { aseptic loosening }\end{array}$ \\
\hline $\begin{array}{l}\text { Cancienne } \\
\text { et al. [15] }\end{array}$ & 2017 & USA & Retrospective & $\begin{array}{l}7763 \text { total hip } \\
\text { ART }\end{array}$ & $\begin{array}{l}\text { HbA1c is a poor predictor of deep infections, however, a level } \\
\geq 7.5 \text { increased infections }\end{array}$ \\
\hline $\begin{array}{l}\text { Tarabichi et } \\
\text { al. [16] }\end{array}$ & 2017 & USA & Retrospective & $\begin{array}{l}1645 \text { knee and } \\
\text { hip ART }\end{array}$ & $\mathrm{HbA} 1 \mathrm{c} 7.7 \%$ is more indicative of infection \\
\hline $\begin{array}{l}\text { Capozzi et } \\
\text { al. [17] }\end{array}$ & 2017 & USA & Retrospective & $\begin{array}{l}663 \text { knee and } \\
\text { hip ART }\end{array}$ & Prediabetes in $31 \%$ and diabetes in $2.6 \%$ \\
\hline $\begin{array}{l}\text { Lavernia et } \\
\text { al. [18] }\end{array}$ & 2017 & USA & Case-control & $\begin{array}{l}120 \text { total joint } \\
\text { ART followed for } \\
5.9 \text { years }\end{array}$ & $\begin{array}{l}\text { No effects of preoperative glycemic control on the length of stay, } \\
\text { hospital costs, or rate of short-term postoperative complications. }\end{array}$ \\
\hline $\begin{array}{l}\text { Cancienne } \\
\text { et al. [19] }\end{array}$ & 2018 & USA & Retrospective & Shoulder ART & Higher infection at perioperative $\mathrm{HbA} 1 \mathrm{c}>8$ \\
\hline $\begin{array}{l}\text { Godshaw et } \\
\text { al. [20] }\end{array}$ & 2018 & USA & Retrospective & $\begin{array}{l}773 \text { total joint } \\
\text { ART }\end{array}$ & $\begin{array}{l}\mathrm{HbA} 1 \mathrm{c} \text { of } 7.45 \text { is suggested (correlated with RBS of } 200 \mathrm{mg} / \mathrm{dl} \\
\text { postoperatively) }\end{array}$ \\
\hline $\begin{array}{l}\text { Kurowicki et } \\
\text { al. [21] }\end{array}$ & 2018 & USA & Retrospective & Total hip ART & Higher perioperative $\mathrm{HbA1c}$ levels increase the cost \\
\hline $\begin{array}{l}\text { Kheir et al. } \\
\text { [22] }\end{array}$ & 2018 & USA & Retrospective & $\begin{array}{l}24,857 \text { primary } \\
\text { total joint ART }\end{array}$ & $\begin{array}{l}\text { Even mild hyperglycemia was significantly associated with } \\
\text { periprosthetic joint infection. Postoperative cut-off was } 137 \\
\text { mg/dl. }\end{array}$ \\
\hline $\begin{array}{l}\text { Shohat et al. } \\
\text { [23] }\end{array}$ & 2018 & $\begin{array}{l}\text { Israel, } \\
\text { USA }\end{array}$ & $\begin{array}{l}\text { Prospective } \\
\text { cohort }\end{array}$ & 1461 knee ART & $\begin{array}{l}\text { Complications noted, no differences between diagnosed and } \\
\text { undiagnosed DM. }\end{array}$ \\
\hline $\begin{array}{l}\text { Lenguerrand } \\
\text { et al. [24] }\end{array}$ & 2018 & UK & Retrospective & $\begin{array}{l}\text { Hip and knee } \\
\text { ART (587) }\end{array}$ & $\begin{array}{l}\text { Hospital stay, pain, and complications increased and attenuated } \\
\text { after controlling for obesity and comorbidities. }\end{array}$ \\
\hline $\begin{array}{l}\text { Ryan et al. } \\
\text { [25] }\end{array}$ & 2019 & USA & Retrospective & 1406 & $\begin{array}{l}\text { Perioperative blood glucose and } \mathrm{HbA1c} \text { are not predictive of } \\
\text { postoperative infections; however, deep and prolonged } \\
\text { infections were observed. }\end{array}$ \\
\hline $\begin{array}{l}\text { Shohat et al. } \\
{[26]}\end{array}$ & 2019 & USA & $\begin{array}{l}\text { Prospective } \\
\text { cohort }\end{array}$ & 1119 & $\begin{array}{l}\text { Fructosamine level of } 293 \mu \mathrm{mol} / \mathrm{I} \text { was identified as the optimal } \\
\text { cut-off associated with complications. }\end{array}$ \\
\hline
\end{tabular}


TABLE 2: The relationship between glycemia and diabetic ART

ART: arthroplasty, DM: diabetes mellitus, HbA1c: glycated hemoglobin, RBS: random blood sugar, FBS: fasting blood sugar.

\section{Discussion}

In the current review, a retrospective study conducted in the USA [5] and including 1948 patients found that $\mathrm{DM}$ and morning perioperative hyperglycemia were predictors for postoperative infection of lower limb ART; the findings were supported by Jämsen et al. [6] from Finland and Stryker et al. [7] in the USA. The latter study also found an $\mathrm{HbA} 1 \mathrm{c}$ of 6.7 is a predictor of postoperative wound infection, and in contradiction, Adams et al. [8] found no differences between patients with diabetes and counterparts without the disease regarding thrombosis, myocardial infarction, and readmission. A cut-off of $\geqslant 7$ of the HbA1c was found to be associated with mortality among patients who underwent total ART. However, there was no association with perioperative joint infection [9]. The findings of Maradit Kremers et al. [10] related postoperative infection to high body mass index, type of surgery, and length of operative time; the findings of increased pain after ART among patients with diabetes could be due to diabetic neuropathy [11]. In the current review, an FBS of $>200 \mathrm{mg}$ and an HbA1c of $\geqslant 8$ were associated with superficial infections and slow improvement $[12,13]$. Maradit Kremers and colleagues in their more recent study [14] found that high preoperative hyperglycemia is a potential risk factor for aseptic loosening, while two retrospective studies with large samples $[15,16]$ showed the association of deep infections with A HbA1c of 7.5 and 7.7. Capozzi et al. [17] reported that nearly one-third of patients who underwent ART were prediabetes, and a case-control study published in the USA [18] showed no effects of preoperative glycemic control on length of stay, hospital costs, or rate of short-term postoperative complications. However, the study conclusion was based on the glycated hemoglobin and only 120 patients were included. Further studies showed conflicting cut-off regarding the association of the glycated hemoglobin and perioperative infections, 8 and 7.45, respectively [19,20]. Another study [21] reported the association of higher glycated hemoglobin and pain, while Kheir et al. [22] in their retrospective study showed that even mild hyperglycemia was significantly associated with periprosthetic joint infection. The postoperative cut-off was $137 \mathrm{mg} / \mathrm{dl}$, and Sohat et al. [23] found no difference between known cases of DM and those who were not diagnosed in terms of postoperative infections. Further studies based their conclusion on the glycated hemoglobin [24] and stated that hospital stay, pain, and complications increased and attenuated after controlling for obesity and comorbidities. A recent study published in the USA [25] found that perioperative blood glucose and HbA1c are not predictive of postoperative infections; however, deep and prolonged infections were observed, and Shohat et al. [26] found that a fructosamine level of $293 \mu \mathrm{mol} / \mathrm{l}$ was identified as the optimal cut-off associated with complications.

\section{Conclusions}

High perioperative hyperglycemia was associated with more ART complications. However, the complications were attenuated after controlling for obesity and other comorbidities. Controlling high body mass index and comorbidities may be needed before ART among patients with diabetes and prediabetes.

\section{Additional Information}

\section{Disclosures}

Conflicts of interest: In compliance with the ICMJE uniform disclosure form, all authors declare the following: Payment/services info: All authors have declared that no financial support was received from any organization for the submitted work. Financial relationships: All authors have declared that they have no financial relationships at present or within the previous three years with any organizations that might have an interest in the submitted work. Other relationships: All authors have declared that there are no other relationships or activities that could appear to have influenced the submitted work.

\section{References}

1. Maradit Kremers H, Larson DR, Crowson CS, et al.: Prevalence of total hip and knee replacement in the United States. J Bone Joint Surg Am. 2015, 97:1386-1397. 10.2106/JBJS.N.01141

2. Hamilton DF, Howie CR, Burnett R, Simpson AH, Patton JT: Dealing with the predicted increase in demand for revision total knee arthroplasty: challenges, risks and opportunities. Bone Joint J. 2015, 97:723-728. 10.1302/0301-620X.97B6.35185

3. Sharma T, Hönle W, Handschu R, Adler W, Goyal T, Schuh A: Incidence of perioperative complications in total hip and knee arthroplasty in patients with Parkinson disease. Arch Orthop Trauma Surg. 2018, 138:765-770. 10.1007/s00402-018-2899-8

4. Tabák AG, Herder C, Rathmann W, Brunner EJ, Kivimäki M: Prediabetes: a high-risk state for diabetes development. Lancet. 2012, 379:2279-2290. 10.1016/S0140-6736(12)60283-9

5. Mraovic B, Suh D, Jacovides C, Parvizi J: Perioperative hyperglycemia and postoperative infection after lower limb arthroplasty. J Diabetes Sci Technol. 2011, 1:412-418. 10.1177/193229681100500231

6. Jämsen E, Nevalainen P, Eskelinen A, Huotari K, Kalliovalkama J, Moilanen T: Obesity, diabetes, and preoperative hyperglycemia as predictors of periprosthetic joint infection: a single-center analysis of 7181 
primary hip and knee replacements for osteoarthritis. J Bone Joint Surg Am. 2012, 18:101. 10.2106/JBJS.J.01935

7. Stryker LS, Abdel MP, Morrey ME, Morrow MM, Kor DJ, Morrey BF: Elevated postoperative blood glucose and preoperative hemoglobin $\mathrm{A} 1 \mathrm{C}$ are associated with increased wound complications following total joint arthroplasty. J Bone Joint Surg Am. 2013, 808:1-2. 10.2106/JBJS.L.00494

8. Adams AL, Paxton EW, Wang JQ, et al.: Surgical outcomes of total knee replacement according to diabetes status and glycemic control, 2001 to 2009. J Bone Joint Surg Am. 2013, 95:481-487. 10.2106/JBJS.L.00109

9. Chrastil J, Anderson MB, Stevens V, Anand R, Peters CL, Pelt CE: Is hemoglobin A1c or perioperative hyperglycemia predictive of periprosthetic joint infection or death following primary total joint arthroplasty?. J Arthroplasty. 2015, 30:1197-202. 10.1016/j.arth.2015.01.040

10. Maradit Kremers H, Lewallen LW, Mabry TM, Berry DJ, Berbari EF, Osmon DR: Diabetes mellitus, hyperglycemia, hemoglobin $\mathrm{A} 1 \mathrm{C}$ and the risk of prosthetic joint infections in total hip and knee arthroplasty. J Arthroplasty. 2015, 30:439-443. 10.1016/j.arth.2014.10.009

11. Rajamäki TJ, Jämsen E, Puolakka PA, Nevalainen PI, Moilanen T: Diabetes is associated with persistent pain after hip and knee replacement. Acta Orthop. 2015, 86:586-593. 10.3109/17453674.2015.1044389

12. Hwang JS, Kim SJ, Bamne AB, Na YG, Kim TK: Do glycemic markers predict occurrence of complications after total knee arthroplasty in patients with diabetes?. Clin Orthop Relat Res. 2015, 473:1726-1731. 10.1007/s11999-014-4056-1

13. Brock TM, Shirley M, Bardgett M, Walker M, Deehan DJ: Inadequate pre-operative glycaemic control in patients with diabetes mellitus adversely influences functional recovery after total knee arthroplasty: Patients with impaired glycaemic control exhibit poorer functional outcomes at 1-year post-arthroplasty. Knee Surg Sports Traumatol Arthrosc. 2017, 25:1801-1806. 10.1007/s00167-016-4249-0

14. Maradit Kremers H, Schleck CD, Lewallen EA, Larson DR, Van Wijnen AJ, Lewallen DG: Diabetes mellitus and hyperglycemia and the risk of aseptic loosening in total joint arthroplasty. J Arthroplasty. 2017, 32:251253. 10.1016/j.arth.2017.02.056

15. Cancienne JM, Werner BC, Browne JA: Is there a threshold value of hemoglobin A1c that predicts risk of infection following primary total hip arthroplasty?. J Arthroplasty. 2017, 32:236-240. 10.1016/j.arth.2017.01.022

16. Tarabichi M, Shohat N, Kheir MM, et al.: Determining the threshold for HbA1c as a predictor for adverse outcomes after total joint arthroplasty: a multicenter, retrospective study. J Arthroplasty. 2017, 32:263-267. 10.1016/j.arth.2017.04.065

17. Capozzi JD, Lepkowsky ER, Callari MM, Jordan ET, Koenig JA, Sirounian GH: The prevalence of diabetes mellitus and routine hemoglobin A1c screening in elective total joint arthroplasty patients. J Arthroplasty. 2017, 32:304-308. 10.1016/j.arth.2016.06.025

18. Lavernia CJ, Heiner AD, Villa JM, Alcerro JC, Rossi MD: Preoperative glycemic control on total joint arthroplasty patient-perceived outcomes and hospital costs. J Arthroplasty. 2017, 32:6-10. 10.1016/j.arth.2016.07.002

19. Cancienne JM, Brockmeier SF, Werner BC: Association of perioperative glycemic control with deep postoperative infection after shoulder arthroplasty in patients with diabetes. J Am Acad Orthop Surg. 2018, 26:238-245. 10.5435/JAAOS-D-16-00784

20. Godshaw BM, Ojard CA, Adams TM, Chimento GF, Mohammed A, Waddell BS: Preoperative glycemic control predicts perioperative serum glucose levels in patients undergoing total joint arthroplasty. J Arthroplasty. 2018, 33:76-80. 10.1016/j.arth.2018.02.071

21. Kurowicki J, Rosas S, Khlopas A, et al.: Impact of perioperative HbA1c on reimbursements in diabetes mellitus patients undergoing total hip arthroplasty: a nationwide analysis. J Arthroplasty. 2018, 33:20382042. 10.1016/j.arth.2018.01.062

22. Kheir MM, Tan TL, Kheir M, Maltenfort MG, Chen AF: Postoperative blood glucose levels predict infection after total joint arthroplasty. J Bone Joint Surg Am. 2018, 15:1423-1431. 10.2106/JBJS.17.01316

23. Shohat N, Goswami K, Tarabichi M, Sterbis E, Tan TL, Parvizi J: All patients should be screened for diabetes before total joint arthroplasty. J Arthroplasty. 2018, 33:2057-2061. 10.1016/j.arth.2018.02.047

24. Lenguerrand E, Beswick AD, Whitehouse MR, Wylde V, Blom AW: Outcomes following hip and knee replacement in diabetic versus nondiabetic patients and well versus poorly controlled diabetic patients: a prospective cohort study. Acta Orthop. 2018, 89:399-405. 10.1080/17453674.2018.1473327

25. Ryan S, Dilallo M, McCoy K, Green C, Seyler T: Diabetes and total joint arthroplasty: infection risk may not be predictable by markers of glycemic control. J Surg Orthop Adv. 2019, 28:127-131.

26. Shohat N, Tarabichi M, Tan TL, et al.: John Insall Award: fructosamine is a better glycaemic marker compared with glycated haemoglobin (HbA1C) in predicting adverse outcomes following total knee arthroplasty: a prospective multicentre study. Bone Joint J. 2019, 101:3-9. 10.1302/0301-620X.101B7.BJJ2018-1418.R1 